\title{
Humanitarian Intervention from Constructivist Perspective: Case Study of China Peace Keeping Operation in Darfur
}

\author{
Rika Isnarti \\ School of International Relations, University of Andalas \\ West Sumatera, Indonesia \\ rikaisnarti@gmail.com
}

\begin{abstract}
Abstrak
Operasi pemeliharaan perdamaian sebagai bagian dari intervensi kemanusiaan erat kaitannya dengan hak asasi manusia. Hal tersebut dianggap sebagai salah satu cara menunjang hak asasi manusia terutama dalam situasi konflik. Esei berikut bermaksud untuk menganalisa lebih jauh perbedaan antara intervensi kemanusiaan dan dukungan terhadap hak asasi manusia, sekaligus alasan negara turut serta dalam operasi pemeliharaan perdamaian sebagai bentuk intervensi kemanusiaan, dilihat dari sudut pandang konstruktivisme. Esei berikut memuat studi kasus operasi penjagaan perdamaian Tiongkok di Darfur. Kemudian, dapat disimpulkan bahwa konstruktivisme memandang hak asasi manusia sebagai suatu norma yang dapat dikembangan melalui gerakan social oleh negara yang menerima norma tersebut. Tiongkok diharuskan menerima hak asasi manusia sebagai salah satu dari norma utama dan turut serta dalam penjagaan perdamaian sebagai tanda penerimaan hak asasi manusia oleh negara. Di tahap ini, Tiongkok dapat disebut sebagai Negara norm cascade, dimana Tiongkok mengakui hak asasi manusia, namun masih mempertanyakan perilaku yang sesuai terhadap norma tersebut.
\end{abstract}

Kata kunci: Tiongkok, Konstruktivis, Penjagaan perdamaian, norma

\begin{abstract}
Peace keeping operation as part of humanitarian intervention is a close issue to human right. It is assumed to be a way to achieve human right particularly in situation of conflict. This essay analyses the difference between humanitarian intervention and the promotion of human rights and reason state join peace keeping operation in humanitarian intervention from constructivist view? This essay chose Case study China peace keeping operation in Darfur. It concludes that Constructivism sees human rights as a norm that can be promoted by social movement as well countries accept that norm. China has to adopt human rights as one of the primary norm and join peace keeping as an idea that this country accepts the human rights norm. In this step China is a norm cascade stage. China receive human rights but still question the appropriate behavior regarding the norm.
\end{abstract}

Keywords: China, Constructivist, peace keeping, norm

\section{Introduction}

Human rights and humanitarian norms are believed as appropriate state behavior and this is state responsibility to protect human rights as agreed on international community ${ }^{1}$. Usually, during conflict there are many human rights violence cases occur such as using force in doing so. Many countries on behalf of international regime form peace keeping to humanitarian

\footnotetext{
${ }^{1}$ Evans, G. \&Sahnoun, M. The Responsibility to Protect. Foreign Affairs.81,6, 2002,P.101
} 
intervention to protect civilian on conflict zone. However, humanitarian intervention does not always promote human rights although the idea is to protect human rights in conflict but to some extend human rights becomes ignorance in humanitarian intervention.

However, there is a dilemma between sovereignty and humanitarian intervention. A state cannot involve in other states internal affairs due to respect to sovereignty. On the other hand, this is state responsibility to protect (R2P) individual human rights. As a result, some states do not want to involve in humanitarian intervention in a state conflict. However, because of moral reason and pressure from international community, sometimes state has to put sovereignty in second place and do humanitarian intervention to keep peace in the world and exercise human rights. Then, there would be a question, why finally a state wants to join in humanitarian intervention?

China is one of states that finally join humanitarian intervention in Darfur and give good respond in this case if compare to international humanitarian involvement in conflict in Kosovo, Rwanda and other countries, include conflict in Darfur before $2007^{2}$. China tends to stand on sovereignty and abstain in United Nation Security Council in every voting about UN humanitarian intervention ${ }^{3}$. China is also known with many human rights cases in its internal. Many reports in UN commission reported about China human rights violence ${ }^{4}$. However, china involves in humanitarian intervention in Darfur and to some extend also promote human rights in here. There is actually difference between humanitarian intervention and human rights. This essay will answer the questions why state join humanitarian intervention and promote human rights from constructivism and what is difference between them.

This essay argues that China's behavior changes to support humanitarian intervention and human rights by joining peace keeping operations because receive international pressure and its willingness to act as international norm accepted by most countries as international community member. There is also norm process that China faced to accept the norms, at this level China is in norm cascade stage. Moreover, this situation requires changing in china's identity and interest in adopting the norm. Wendt argues that, state can change its behavior, identity and interest due to impression from international community that constructed their shared idea and vice versa ${ }^{5}$.

\section{Constructivism, Human rights, and Humanitarian Intervention}

\footnotetext{
${ }^{2}$ Lee, P. K., Chan, G. \& Chan, L.-H. 2012. China in Darfur: Humanitarian Rule-Maker Or Rule-Taker? Review Of International Studies, 38, P. 424.

${ }^{3}$ China mainly justified its abstentions on Resolutions 1556, 1564, 1591, 1593, 1672, and 1706 on the basis of its disagreement on humanitarian intervention as solution to conflict problem in conflict zone indicated China disagree about humanitarian intervention.

WU, C. 2010. Sovereignty, Human Rights, and Responsibility: Changes in China's Response to International Humanitarian Crises. Journal of Chinese Political Science, 15, p.80.

${ }^{4}$ Dingding, C. 2009. China's Participation In The International Human Rights Regime: A State Identity Perspective. Chinese Journal Of International Politics, 2, P. 341.

${ }^{5}$ Wendt, A. Four Sociologies Of International Politics, in Social Theory Of International Politics. Cambridge: Cambridge University Press. 1999. P. 1
} 
Constructivism analyses the relation between structure, norm, and actor ${ }^{6}$. Constructivism sees actors and structure is not stable and fix and also influence each other. Actor acts or interacts in its behavior or develops its identity and interest with others in international system based on norm occurs in the society. In other words, actor's behavior defined by social structure through its norm. On the other hand, actor can develop new norm in its structure while interact with other and influence or change the structure ${ }^{7}$. According to Wendt's theory on the relationship among identity, interest, and behavior, an actor's identity affects its interest, interest is rooted in identity, and identities and interests determine states' behavior that constructed by domestic politics and international system. Further he argues that identity can be produced through interaction and how states threat others from norm that develop or exist $^{8}$. In an effort to achieve these interests state attempt to persuade others. They create affecting a norm cascade-, a step where states adopt norms due to international pressure although there is no pressure from domestic.

As a result state is drawing on the moral, legal and the constitutional normative context as well as material power they attempt to establish a legitimate norm that can be accepted in international community ${ }^{9}$. Further, interest is not material in constructivism but intersubjectivity. Interest of states will be created when they interact with other states in international system and its interest can change from time to time depend on their interaction. When a state interacts with others, to some extend it will shape what behavior and role they should play and how the state act will be influenced by others that's called as intersubjectivity. That is why in constructivist, it is said interest is created from intersubjectivity.

There are three stages in norm cycle to influence actor in international community; emergence, cascade and internalization ${ }^{10}$. Norm emerges or known as norm entrepreneurs is a norm promoted actively by actor with appropriate behavior. In second stage there is norm cascade. This is when numbers of actors has implemented the norm in previous stage. At this point, norm entrepreneurs reach a 'tipping point'. In this situation state can receive the norm and there is no pressure from domestic. Usually, state also determines its interest and behavior based on the norm that has be cascaded ${ }^{11}$. However, there is still number of country that cannot receive this norm, and consider to apply the norm, they are not internalized. Finally norm reaches final stage that internalization and norm are not questioned and received

\footnotetext{
${ }^{6}$ Hoffman, M. J. What's Global About Global Governance? A Constructivist Account. In: Hoffman, M. J. \& Ba, A. D. (Eds.) PrespectivesOn Global Governance, Coherence, Contestation And World Order. New York: Routledge. 2005. P. 115

${ }^{7}$ Dixon, S. Humanitarian Intervention: A Novel Constructivist Analysis Of Norms And Behaviour. Journal Of Politics \& International Studies, 9, 2013, P.136.

${ }^{8} \mathrm{Wu}$, P. 82

${ }^{9}$ Glanville, L. Norms, Interests And Humanitarian Intervention. Master, Macquarie University.2005 P. 19

${ }^{10}$ Finnemore, M. \&Sikkink, K. 1998. International Norm Dynamics And Political Change. International Organization, 52,1988,P. 896.

${ }^{11}$ Dixon, P.160
} 
as an appropriate behavior, while most of international community member have received it as norm and implement it in their daily life ${ }^{12}$.

Constructivist sees human rights is a norm and humanitarian intervention is idea to realize the norm. At this point, human rights is norm cascade stage. Many states apply the norm but not as an action taken for granted or are not questioned anymore. In practice, how to implement an ideal norm is still questioned. For example in what idea human rights have to be the best practice implementation, if state believes it is a norm. If humanitarian intervention (the idea) is believed as something ideal to implement in human rights norm, other states is still arguing whether it is the good practice one in human rights norm or not, they still argue that there is another idea to apply human rights as a norm rather than accept humanitarian intervention. They are still questioned appropriate behavior in norm that has been accepted.

States have to follow the norm in international system because of their identity. States pursue human rights goals for reasons to do with their identity and status ${ }^{13}$. According to Finnemore and Sikkink, a state needs legitimation ${ }^{14}$. One of the ways to gain legitimation is by having the same identity with others in international system so they legitimate as friend. This is also will be easier to state to pursue its interest because they interact with their friend as they have the same identity than interact with their enemy which have different norm and identity in international system.

Moreover, in order to accept a norm globally and implement appropriately, norm is not always promoted by state. There is international organization and social movement which also promote the same value about the norm ${ }^{15}$. They become an agent that pressure state to accept particular norm and promote it within the state. For example, there are many NGOs who operate in particular country aiming to promote several norms in international community to a country where they operate. For example, there is human rights in China (HRIC) as non-governmental organization who promote about human rights in China to raise China attention about human rights problem in China and how to respect about it. To make a state accept a norm usually the can do pressure to state, guide a state to ratify particular convention so there is a legal basis for state to act based on norm they adopt through the agreement and then monitor compliance with international standard. Here, constructivism also sees non state actors as an influent agent who interacts in international system.

According to Kuperman, Humanitarian intervention is the use of diplomatic, economic, and military resources by one or more states or international organizations intended primarily to protect civilians who are endangered in intervene state. The civilian might be at risk human rights violations, social disruption and others ${ }^{16}$. Another definition is given by J. L. Holzgrefe

\footnotetext{
${ }^{12}$ Finnemore, M. \&Sikkink, p.904

${ }^{13}$ Dower, Nigel. "Human Rights And International Relations." The International Journal Of Human Rights 1, No. 1, 1997, p. 87

${ }^{14}$ Finnemore, M. \& Sikkink, P.903

${ }^{15}$ Solomon, Ty. "Norms And Human Rights In International Relations." Political Studies Review 4, No. 1,2006, p.40

${ }^{16}$ Kuperman, A. J. Humanitarian Intervention. In:Goodhart, M. (Ed.) Human Right Politics And Practice. United Kingdom: Oxford University Press. 2013.291
} 
and Allen Buchanan in Herta(2013). Humanitarian intervention defines as an activity undertaken by state, a group within a states or an international organization which use force aimed at preventing or ending widespread and grave violations of the fundamental human rights of individuals others than its own citizens, without the permission of the state within whose territory force is applied. This definition emphasizes whether states may use force to protect human rights ${ }^{17}$.

The purpose of humanitarian intervention cannot separate from promoting human rights. States join humanitarian intervention to stop human rights violation that usually faced by civilian in conflict, such as humanitarian intervention programs provide humanitarian aid, resettlement of civilians, and other cases to reduce human rights violations cases. For example 250,000 Sudanese refugees surviving in camps in eastern Chad assisted by humanitarian intervention that before they were likely to be killed because they had not fled the fighting. ${ }^{18}$

However, humanitarian intervention cannot separate from use of force that can trigger human rights violation as well. Althoughthe aim of humanitarian intervention is to promote human rights sometimes it can cause opposite effect. Humanitarian intervention uses impartiality and neutrality principle ${ }^{19}$ that aid is delivered based on basic need without considering the party who received it whether they are political or military recipient and the aid will not affect the balance of power. However, in practice humanitarian aid delivered by humanitarian intervention troops influence balance of power and trigger bigger conflict. As a result, more human rights violations faced by civilian because of conflict. For example, in 1993 in Somalia's conflict, during "black Hawk Down" incident, U.S and UN troops that supposed to be humanitarian intervention troops and reduce the conflict, killed at least 500 Somalis on and as many as 1,500 during the rest of the mission that more than halfof them women and children ${ }^{20}$ In Bosnia, 1995,US troops backed Croatianand Bosnian Muslim forces to block aggression from Slobodan Milosevic. These forces influenced the balance of power of party in conflict and cause big number of human rights violations faced by other parties. ${ }^{21}$

\section{China in Humanitarian Intervention Conflict in Darfur}

Conflict in Darfur exploded in 2003 and has been killed about 300,000 people and 2,5 million its citizen become refugee ${ }^{22}$. Seeing this conflict United Nation Security Council thinks the importance of international community to intervene to solve the conflict. As a result, since

\footnotetext{
${ }^{17}$ Herta, L. M. Jus In Bello And The Solidarist Case For Humanitarian Intervention. From Theory To Practice. StudiaUniversitatis Babes-Bolyai. StudiaEuropaea, 58,2013. P.3

${ }^{18}$ Seybolt, T. B. Judging Success And Failure. In:Seybolt, T. B. (Ed.) Humanitarian Military Intervention The Conditions For Success And Failure New York: Oxford University Press.2008.P. 45

${ }^{19}$ Kuperman, p.295

${ }^{20}$ Valentino, B. A. The True Costs Of Humanitarian Intervention The Hard Truth About A Noble Notion. Foreign Affairs, 60, 2011.P.64.

${ }^{21}$ Seybolt, T. B. Controversies About Humanitarian Military Intervention. In:Seybolt, T. B. (Ed.) Humanitarian Military Intervention The Conditions For Success And Failure New York: Oxford University Press.2008. P.5 ${ }^{22}$ Lee, P. K., Chan, G. \& Chan, L.-H..P. 429
} 
2004 there are many UN resolutions to cure conflict in Darfur. However as one of UN Security Council members China mostly had abstained resolution on Darfur until 2006. In 2007 China finally voted to establish African Union and United Nation hybrid operation in Darfur (UNAMID) behind resolution 1769 to deploy hybrid humanitarian intervention 26,000 troops ${ }^{23}$. Having said that, Darfur conflict is the first conflict that China involved in humanitarian more than other conflicts such as conflict in Kosovo, Rwanda, and others.

However, this resolution and other resolutions do not stop conflict in Darfur although China has been involved in humanitarian intervention. It is believed that from international perception China's relation with Sudan slows down to end the conflict ${ }^{24}$. There is a relation between china energy security and supporting conflict in Sudan. China buys two-third Sudanese crude oil to fulfil its energy security and Sudan spend its majority budgets to import weapons from China especially during conflict ${ }^{25}$.

China is sensitive about sovereignty. China believes that international community should respect the principle of sovereignty and non-intervene in internal state affairs in any condition. This country has bad history about external affairs intervention such as Tiananmen crisis in 1989 where external party entered to china in the name of human rights and democracy but brought negative effects to China. However, china does not want to isolate from the international system, as a member of international system China has to apply norms that accepted in its community to be its part. One of the norms is human rights.

To implement China behavior as the international system member indicating China also apply the same norm, China finally passed the resolution 1769. China wants to see as a country that respect to human rights through humanitarian. As a result, from 2007, china also actively involves to resolve conflict in Sudan. Besides send its police and army to peacekeeping, China also negotiates with Sudanese Government to stop the conflict, give pressure to Sudan government, and other actions.

Analyzing from constructivism, there is reason why China finally voted in 1769 resolution and involved in humanitarian intervention if before China tent to abstain in voting about humanitarian intervention in UNSC. As constructivist explains, state can change its behavior and identity due to interaction in international system to achieve its interest ${ }^{26}$. Here, China faced the same situation in international system. International system give pressure to China by blaming China because partnering with Sudan for oil and do not give economic sanction for Sudan in abusing human right. Social movements also give pressure and ask China to change its behavior. Human rights activists, NBA athletes, US congressmen threatened will

\footnotetext{
${ }^{23}$ African Union/UN Hybrid Operation in Darfur, 'UNAMID Background',http://www.un.org/en/ peacekeeping/missions/unamid/background.shtml accessed on 9 October, 2014

${ }^{24}$ Davis, J. E. 2011. From Ideology To Pragmatism: China's Position On Humanitarian Intervention In The Post-Cold War Era. Vanderbilt Journal Oftransnational Law, 4, 2011. P. 266.

${ }^{25}$ Lee, p. 429

${ }^{26}$ Glenville,p.3
} 
not participate in Beijing Olympics 2008 and boycott the games if China did not take action in Sudan conflict ${ }^{27}$. As a result, to achieve its interest because at the time China has to secure its energy and many of its citizen have oil business in Sudan that China has to protect and have to make sure the success of Olympics, China had to change its behavior to Sudan from abstain to vote in UN and give pressure in economy to Khartoum to let UN peacekeeping operation in Sudan. ${ }^{28}$

This situation indicates that China is in stage of "norm cascade" while respect to human rights is seen as an act done by good countries and require others to act the same but is not something taken for granted. There is still question on what behavior is appropriate. May be to some extent China has agreed and received human rights as a norm proven by China actively contribute to send aid to area in conflict behind United Nations ${ }^{29}$ but China still question is humanitarian intervention good behavior in human rights while there is a dilemma between sovereignty and humanitarian intervention.

In order to maintain its name and continue to interact and pursue its interest, China has to receive the norm and the idea to change its behavior although before China did not want to put humanitarian intervention above sovereignty. If China still exists in its norm to ignore humanitarian intervention and stay on sovereignty, China cannot achieve its interest because of pressure from international community. International Community cannot allow China to interact with them as having different identity. As a result, China has to change its primary norm to be a country who also respect to humanitarian intervention. This is not a single and short process, in order to promote this idea and norm, international community has to promote, act and give pressure to others to receive the norm promoted.

Besides to secure its interest, and as a process to receive norm in stage of norm cascade, China's reason to accept humanitarian intervention and act more to Darfur because of reputation. Finnemore and Sikkink argue that reputation is the motivation for a state to accept international norm. ${ }^{30}$ The norm of respecting human rights has become respect highly in the international community. So, the countries which participate in this norm that implement through peacekeeping, giving contribution to human rights can receive good reputation.

From this point we can conclude that, international system is something dynamic and the value can be intersubjectivity. State decides to receive a norm because there is actor who promotes it through socialization and sanction in order to be received as general norm or internalization. China finally receive and act in humanitarian intervention as an idea of human rights because its interactions with others in its structure. If China cannot practice the

\footnotetext{
${ }^{27}$ Tull, D. M. China's Engagement In Africa: Scope,Significances. The Journal Of Modern African Studies, 44, 2006. 469.

${ }^{28}$ Contessi, N. P. Multilateralism, Intervention And Norm Contestation: China's Stance On Darfur In The Un Security Council. Security Dialogue, 41,2010.P.330.

${ }^{29}$ Contessi, p.322

${ }^{30}$ Chen, J. 2008. Explaining The Change In China's Attitude Toward Un Peacekeeping: A Norm Change Perspective. Journal Of Contemporary China, 18, 2008.P. 160
} 
same norm, china will not be seen as part of international community. Moreover, a state such as china also can change its identity from the one who support sovereignty and give less attention to humanitarian intervention because of this structure and affect its interest while to achieve it, China has to replace the norm and to maintain its reputation.

Humanitarian intervention does not always promote human rights while human rights could be done without humanitarian intervention. However, one of the ways to promote human rights is through humanitarian intervention through giving aid, save civilian to stay in camp to avoid kill by fighting party in conflict, empower their rights to stop conflict, and so on.

There are several different humanitarian interventions from human rights in practice. As its name, humanitarian intervention usually did by external party while internal affairs such as civilian in the country or social movement in the country are party suffer in human rights violations during conflict. However, human rights also can be promoted by social movement within country.

Humanitarian intervention cannot be separated from use force or there is military force in humanitarian intervention while human rights do not use force to achieve its aim. Although to promote human rights sometimes international community gives pressure to a target country, they do not use military to force them. Usually they only boycott, protest, and others such as China Olympic case that will be blocked by human rights activist if China did not support humanitarian intervention in Darfur. However, we cannot associate humanitarian intervention always use force, but this activity is still common. We can see that in every humanitarian intervention there is peace keeping troops that bring gun and as explain before sometimes there is conflict between humanitarian intervention troops that cause human rights abuses.

To explain China case in promoting human rights in Sudan from constructivism, can be seen as China acts as norm entrepreneur agent in promoting human rights rather than use humanitarian intervention to achieve its aim and respect to sovereignty. Constructivism sees norm cycle in influencing state behavior and identity. A state can be norm follower, or in level cascade as well norm entrepreneur that a state promote particular norm to others to adopt.

As we know before, China position in human rights is countless compare to other states such as US, that seen human rights as a norm and the obligation to other states to intervene in the name of human rights. Moreover, china also respect the moral of sovereignty.

To promote human rights without intervention and act based on norm that China believe in, in 2006 China initiated to create a hybrid UN-AU force ${ }^{31}$. This is as a respond to the idea that Sudanese and AU rejected outside intervention that means humanitarian intervention created by UN could be useless. This idea is based on China principle that humanitarian intervention cannot be made without consent of sovereignty state target and they respect on

\footnotetext{
${ }^{31}$ Alden, C. China In Africa. Survival, 47,2005.P.150
} 
humanitarian $^{32}$. If we consider human rights through intervention we have to respect the intervened state's sovereignty to achieve our aim. Otherwise, humanitarian intervention can be useless and human rights purposes will not be achieved. This hybrid troops finally can be accepted by Khartoum with the bigger number of African troops than UN troops as their condition. This decision can be received by them because China also influence and pressure Khartoum with economic sanction to stop buying the crude oil and this action was confirmed by Zhai Jun, Chinese diplomat. ${ }^{33}$ This is along with Philips in Jokic (2003) believes, If the conflict party disagree with foreign intervention to its country, they can create bigger conflict by abandoning human rights and their own civilian. ${ }^{34}$

China gives sanction to Sudan to stop buying its crude oil in one side can reduce Sudan income so it can also reduce their budget to buy gun to stop conflict. This sanction, will make Sudan to think twice to create conflict compare to develop its economy. In addition China shows its respect to Sudan sovereignty and Sudan condition about humanitarian intervention that indicate China to ask Sudan to also respect the norm in international community to receive aid and intervention from external. As said before, reputation also play important part in a country accept particular norm. If Sudan wants to show itself as a member of international community, it then will follow the norm occur to them, in this case is accept humanitarian intervention.

Further, China in promoting human rights in Darfur is focusing on develop the citizen rather than intervene the Sudan policy or use force. China since 2008 actively send aid to Sudanese to start their life normally and stop live in camp. China also Show its solidarity to Sudanese government in helping its citizen. China gives portable rooms to Sudanese that can be used as classrooms for school or clinics in hospital. This country also spend 50 million dollars on development projects in Darfur, including $85 \mathrm{~km}$ of water pipelines that can be used for drinking water ${ }^{35}$. Moreover, China believes that in promoting human rights we do not have to attach any political condition that can worse condition in Sudan, but we can help them through development project to help Sudanese achieve its rights. ${ }^{36}$

These new rules provide China with adequate protection against external intervention into internal affairs in the name of human rights. ${ }^{37}$ China example on Darfur show us an example how structure and norm influence agent to act and identify its interest and vice versa, how agent change structure.

\footnotetext{
${ }^{32}$ Lei, Z. Two Pillars Of China's Global Peace Engagement Strategy: Un Peacekeeping And International Peacebuilding. International Peacekeeping, 18, 2011 P.348.

${ }^{33}$ Chen, M. E. Chinese National Oil Companies And Human Rights. Orbis, 51, p.50.

${ }^{34}$ Philips, M.Humanitarian Intervention and Moral Theory. In: JOKIC, A. (ed.) Humanitarian Intervention Moral and Philosophical Issue. Lancashire: Zack Taylor.2003.p71

35Xinhua, China provides more humanitarian aid to Darfur, in http://sudantribune.com/spip.php?article26144 accessed 19 October, 2014

${ }^{36}$ Rogers, P. D.ChinaAnd United Nations Peacekeeping Operations In Africa. Naval War College Review.2007.P.73

${ }^{37} \mathrm{Wu}, \mathrm{P} .98$
} 
This shows us that in order to promote human rights, humanitarian intervention does not always have to use force. Promoting human rights could be develop or empower citizens to reach their economy rights. Moreover, as long as humanitarian intervention is not influence the balance of power and do not use force for bad purpose, the aid in humanitarian intervention can achieve its aim, save human rights. In addition, China case show us that in international system actor can act as norm follower as norm entrepreneur, in order to gain its identity and interest that can influence the international system structure.

\section{Conclusion}

Constructivism sees relation among actor, structure and its behavior. Agent's identity and interest influenced by the norm occurred in international system. So, a state can change the norm that it adopt as a state can promote a norm to be adopted by others. Constructivism sees human rights as a norm that can be promoted by social movement as well countries accept that norm.

Humanitarian intervention is an action taken by a state or a group of states to prevent the conflict condition in particular area that usually use force. Humanitarian intervention is different from human rights although one of the ways to promote human rights is through humanitarian intervention. The difference between humanitarian intervention and promoting human rights is in actor and the way it achieve. Humanitarian is usually promote human rights from external party and could use force while human rights can be promoted by internal and external party in the country. To promote human rights, the promoters can use pressure so the target country can accept the human rights as a norm but in humanitarian intervention, a target is forced to receive the norm. Sometimes, humanitarian intervention can cause human rights violations while many peacekeeping troops join the conflict fight and killed civilian. It means this is not always humanitarian intervention gain human rights.

China is a country that primarily places sovereignty in interaction to human rights therefore this country pays less attention regarding these issues. However, because of the interaction with other countries and maintain its position China has to adopt human rights as one of the primary norms and join humanitarian intervention. In this step China is a norm cascade stage. China receives human rights but still question the appropriate behavior regard the norm. China has to accept the human rights norm because to gain its interest and maintain its reputation and identity in international system. There have been changes in China's identity as well as in the international discourse on international humanitarian intervention, and that China's identity change made itself more concerned about its national image and more sensitive to international human rights and humanitarian norms, which has brought about the changes in China's response to international humanitarian crises. ${ }^{38}$

However, China also can act as norm entrepreneur in order to promote its human rights without humanitarian intervention commonly associate with using force. China use economic sanction and economic development to promote human rights in Sudan. As a respect to human rights, China actively distribute aid to Sudan and try to empower its citizen through economy beside

${ }^{38}$ TAYLOR, I. 2008. Sino-African Relations and the Problem of Human Rights. African Affairs, 107,2008.p.73 
give pressure to Sudan economy in this term stop crude oil business if Sudan does not give attention to human rights abuses in the country.

\section{References cited in text}

African Union/Un Hybrid Operation In Darfur, 'UnamidBackground',Http://Www.Un.Org/En/

Alden, C. 2005. China In Africa. Survival, 47, 147-164.

Chen, J. 2008. Explaining The Change In China's Attitude Toward Un Peacekeeping: A Norm Change Perspective. Journal Of Contemporary China, 18, 157-173.

Chen, M. E. 2007. Chinese National Oil Companies And Human Rights. Orbis, 51, 41-54.

Contessi, N. P. 2010. Multilateralism, Intervention And Norm Contestation: China's Stance On Darfur In The Un Security Council. Security Dialogue, 41, 323-344.

Davis, J. E. 2011. From Ideology To Pragmatism: China's Position On Humanitarian Intervention In The Post-Cold War Era. Vanderbilt Journal Oftransnational Law, 4, 217-283.

Dingding, C. 2009. China's Participation In The International Human Rights Regime: A State Identity Perspective. Chinese Journal Of International Politics, 2, 399-419.

Dixon, S. 2013. Humanitarian Intervention: A Novel Constructivist Analysis Of Norms And Behaviour. Journal Of Politics \& International Studies, 9, 126-173.

Dower, N. 1997. Human Rights And International Relations. The International Journal of Human Rights, 1, 86-111.

Evans, G. \&Sahnoun, M. 2002. The Responsibility To Protect. Foreign Affairs.P.99-111

Finnemore, M. \&Sikkink, K. 1998. International Norm Dynamics And Political Change. International Organization, 52, 887-917.

Glanville, L. 2005. Norms, Interests And Humanitarian Intervention. Master, Macquarie University.

Herta, L. M. 2013. Jus In Bello And The Solidarist Case For Humanitarian Intervention. From Theory To Practice. StudiaUniversitatis Babes-Bolyai. StudiaEuropaea, 58, 5-47.

Hoffman, M. J. 2005. What's Global About Global Governance? A Constructivist Account. In: Hoffman, M. J. \& Ba, A. D. (Eds.) PrespectivesOn Global Governance, Coherence, Contestation And World Order. New York: Routledge.

Kuperman, A. J. 2013. Humanitarian Intervention. In:Goodhart, M. (Ed.) Human Right Politics And Practice. United Kingdom: Oxford University Press.

Lee, P. K., Chan, G. \& Chan, L.-H. 2012. China In Darfur: Humanitarian Rule-Maker Or RuleTaker? Review Of International Studies, 38, 423-444.

Lei, Z. 2011. Two Pillars Of China's Global Peace Engagement Strategy: Un Peacekeeping And International Peacebuilding. International Peacekeeping, 18, 344-362. 
Humanitarian Intervention from Constructivist Perspective: Case Study of China Peace Keeping Operation in Darfur

Peacekeeping/Missions/Unamid/Background.Shtml Accessed On 9 October, 2014

Philips, M. 2003. Humanitarian Intervention And Moral Theory. In:Jokic, A. (Ed.) Humanitarian Intervention Moral AndPhilosopical Issue. Lancashire: Zack Taylor.

Rogers, P. D. 2007. China And United Nations Peacekeeping Operations In Africa. Naval War College Review.

Seybolt, T. B. 2008. Controversies About Humanitarian Military Intervention. In:Seybolt, T. B. (Ed.) Humanitarian Military Intervention The Conditions For Success And Failure New York: Oxford University Press.

Seybolt, T. B. 2008. Judging Success And Failure. In:Seybolt, T. B. (Ed.) Humanitarian Military Intervention The Conditions For Success And Failure New York: Oxford University Press.

Solomon, T. 2006. Norms And Human Rights In International Relations. Political Studies Review, 4, 36-47.

Taylor, I. 2008. Sino-African Relations And The Problem Of Human Rights. African Affairs, 107, 63-87.

Tull, D. M. 2006. China's Engagement In Africa: Scope,Significances. The Journal Of Modern African Studies, 44, 459-479.

Valentino, B. A. 2011. The True Costs Of Humanitarian Intervention The Hard Truth About A Noble Notion. Foreign Affairs, 60, 60-73.

Wendt, A. 1999. Four Sociologies Of International Politics. Social Theory Of International Politics. Cambridge: Cambridge University Press.

Wu, C. 2010. Sovereignty, Human Rights, And Responsibility: Changes In China's Response To International Humanitarian Crises. Journal Of Chinese Political Science, 15, 71-97.

Xinhua, China Provides More Humanitarian Aid To Darfur, In Http://Sudantribune.Com/Spip.Php?Article26144 Accessed 19 October, 2014

\section{References not cited in text}

Dunne, T. \& Hanson, M. 2013. Human Rights In International Relations. In:Goodhart, M. (Ed.) Human Right Politics And Practice. United Kingdom: Oxford University Press.

Lee, W. 2013 China's Stand On Humanitarian Intervention And R2p: Challenges And The Problematic "West"? International Journal Of China Studies, 4, 469-484.

Spalding, L. J. 2013. A Critical InvestigationOf The International Relations Theories That Underpin The Debate On Humanitarian Intervention. International Public Policy Review, 7, 1-16.

Tiewa, L. 2012. China And Responsibility To Protect: Maintenance And Change Of Its Policy For Intervention. The Pacific Review, 25, 153-173.

Zhu, L. 2009. Chinese Practice In Public International Law: 2008*. Chinese Journal of International Law, 8, 493-551. 